occurred to him for considering the practical aspect of the planning of science laboratories which led eventually to an interest in architecture.

It is natural therefore that Mr. Munby's principal works as an architect should lean towards science. Many public schools have had the benefit of his experience. He was responsible for the new science buildings at Clifton College, Highgate School, Beaumont College, University College of North Wales at Bangor, Gresham's School, Hereford Cathedral School, Shrewsbury School, Dover College, and for redesigning the science departments at Uppingham and Cheltenham, and at the Chelsea Polytechnic. He acted also as consultant for the Institute of Tropical Medicine in Shanghai, and for the recently erected science department at Malvern College.

Mr. Munby's publications include: "Notes on Polarised Light" (1894), "Introduction to the Chemistry and Physics of Building Materials" (1909), "Laboratories, their Planning and Fittings" (1921), and "School Laboratory Fittings" (1929).

J. R. S.

\section{Mr. M. W. Hilton-Simpson}

WE regret to record the death of Melville W. Hilton-Simpson, anthropologist and African traveller, which took place on March 17 at the age of fiftyseven years.

Hilton-Simpson was the son of the Rev. William Hilton, who added Simpson to his surname in 1888; he was educated at Wellington and Exeter College, Oxford, where he obtained the degree of B.Sc. and the diploma in anthropology. On leaving Oxford, he specialized in the study of African ethnology in the field, making his first journey in North Africa and the Sahara in 1903. His next expedition was to West Africa with Emil Torday as leader, and Norman Hardy, the artist. This ethnological expedition, of the first importance as it proved to be, was carried out on behalf of the British Museum. It covered much unmapped territory in the Kasai basin of the Congo, and brought back valuable anthropological information relating to the tribes of the area, especially the Bushongo, a rich collection of ethnographical specimens, more especially examples of the art of the Congo peoples, and a gallery of paintings by Norman Hardy, which were as remarkable for their accuracy in representing the physical characters of the people, their dress and ormament, as they were for their high artistic merit.

Hilton-Simpson's interests, however, centred not so much in tropical Africa as in the ethnological problems of the northern area of the continent, and more especially in the Berber peoples. For a number of years, each season found him travelling in North Africa, while from 1912 onward he specialized still further in the study of the Algerian Berbers. Seven winters in succession were spent in travelling in the Aurès mountains, where the sporting tastes of himself and his wife established friendly relations with a sporting people and won them exceptional facilities for their investigations. Mrs. Hilton-Simpson's skill as a hockey player not only secured her a place of pre-eminence in the Shawia women's national game, but also gave her their intimate confidence, to the lasting gain of ethnological science.

The work of these years of travel was recorded in "Among the Hill-Folk of Algeria" and "Arab Medicine and Surgery", and in papers in the Geographical Journal, the publications of the Royal Anthropological Institute and elsewhere. An especially important contribution to the study of these peoples was a series of cinematograph films of Berber life and industry, taken by $\mathrm{Mr}$. J. Haessler, an American anthropologist, who accompanied them on certain of their expeditions. Apart from his general account of these peoples, Hilton-Simpson's most valuable contribution to the study of their culture was his investigation of their practice of trephining. He made a collection of the instruments used for this purpose, and showed that, like a number of other elements in their culture, the practice was to be traced back to Roman times.

Hilton-Simpson, who served on the Western Front in the Great War and held the rank of captain, was a Chevalier of the Légion d'Honneur and was awarded the Rivers Medal of the Royal Anthropological Institute for anthropological work in the field in 1932.

\section{Lady Gomme}

Bx the death of Lady Gomme, which took place on January 5 at the age of eighty-five years, folklore studies in Great Britain have lost a staunch supporter of long standing. With her husband, the late Sir George Laurence Gomme, whom she, as Alice Bertha Merck, married in 1875, she took a prominent part in the early activities of the newly constituted. Folk-Lore Society, of which they were among the founders. Throughout their married life, and after her husband's death, her organizing ability, her knowledge of her subject and its personnel, and her keen critical faculty, gave her, as of right, a foremost place in every movement for promoting the recording and scientific study of folk beliefs, customs and institutions. Lady Gomme helped to found the two societies, now merged, devoted to the study of folkdance and song, and strongly influenced the late Sir Cecil Sharp in his work of collecting folk-songs and dances. She herself was the author of two works, which have long been regarded as standard books of reference and models of their kind- "Children's Singing Games, with the Tunes to which they are Sung" (1894, Second Series, 1895) and "A Dictionary of British Folk-Iıre, Vol. 1 : Traditional Games of England, Scotland and Ireland" (Pt. 1, 1894 ; Pt. 2, 1898).

\section{Ww regret to announce the following deaths :}

Mr. F. G. L. Bertram, deputy director of civil aviation from 1926 until 1935, on March 24, aged sixty-two years.

Capt. T. S. Taylor, founder and a director of Taylor, Taylor and Hobson, Ltd., manufacturing opticians, on March 14, aged seventy-four years. 